\title{
УOBOЗНАВCTBO. ПUTEDATУРОЗНАВCTBO
}

\author{
УДК [811.161.2'373:2]:821.161.2-1 \\ DOI https://doi.org/10.24919/2308-4863/35-8-16
}

\begin{abstract}
Наталія АДАХ,
orcid.org/00000002-4146-4990

кандидат філологічних наук,

доцент кафедри української мови імені професора К. Ф. Шульжука

Рівненського державного гуманітарного університету

(Рівне, Україна) arsenivna@gmail.com
\end{abstract}

Наталія ГАВРИЛЮК, orcid.org/0000-0003-0225-3258

кандидат філологічних наук, дочент кафедри української мови імені професора К. Ф. Шульжука Рівненського держсавного гуманітарного університету

(Рівне, Україна) gavryluk.nat@gmail.com

\section{АВТОРСЬКІ ЛЕКСИЧНІ НОВОТВОРИ РЕЛІГІЙНОЇ ТЕМАТИКИ В ПОЕЗЇ̈ ВАСИЛЯ БАРКИ}

У сучасному мовознавстві лексика на позначення релігійних понять неодноразово ставала предметом дослідження вчених. Проте у більшості наукових розвідок висвітлюються переважно особливості узуальної лексики художнього, публіцистичного і конфесійного стилів. Неологічна лексика зазначеної тематики, зафіксована у художніх текстах, розглядалася лише в поодиноких праиях. У пропонованій статті проаналізовано семантичні особливості авторських лексичних новотворів релігійної тематики, виявлених у поезї̈ В. Барки.

Аналіз фактичного матеріалу дозволив виділити з-поміж усього корпусу новотворів на позначення релігійних понять інновації з такими диференційними семами: «щасливий», «щастя, блаженство»; «свічка»; «молитва»/«твір релігійного змісту»; «божественна сила»; «жертовник»; «одяг»; «иерковне приладдя»; «будівля, де відбуваються богослужіння»; «смерть/кінещь»; «пекло». Помічено, щуо наведені інновації відзначаються здебільиого позитивною очінною семантикою. Негативне забарвлення характерне для новотворів, у семантичній структурі яких виділяються семи «муки/мученик»; «противник віри».

Окремо проаналізовано лексико-семантичну групу назв осіб, пов'язаних із релігійною сферою. Виявлено, шьо авторські назви осіб часто є контекстуальними синонімами до узуальних лексем, порівняно з якими є значно експресивніиими.

Особливу увагу звернено на авторські номінації релігійної тематики із символічним значенням. У изьому аспекті детально проаналізовано авторські лексичні новотвори з диференційними семами «змій»/«дракон»; «грім», «блискавка». Спостережено, щзо В. Барка, звертаючись до релігійних вірувань, вказує на вічну боротьбу Бога $i$ чорта, добра $і$ зла, на умовне протистояння між світлом і темрявою. Ця противага представлена в оказіональних іменниках, щз вступають між собою в антонімічні відношення, у результаті чого маємо приклад неологічних антонімів, щзо загалом не є характерним для оказіональної словотворчості якогось одного поета.

Констатовано, щчо для В. Барки характерне використання сакральної лексики і створення на ї̈ основі нових слів, які органічно вплітаються в поетичний контекст відповідної тематики, оскільки на світогляд В. Барки великий вплив мала релігія, особливо християнство і Біблія.

Ключові слова: авторський лексичний новотвір, лексична інновачія, сакральна лексика, сема.

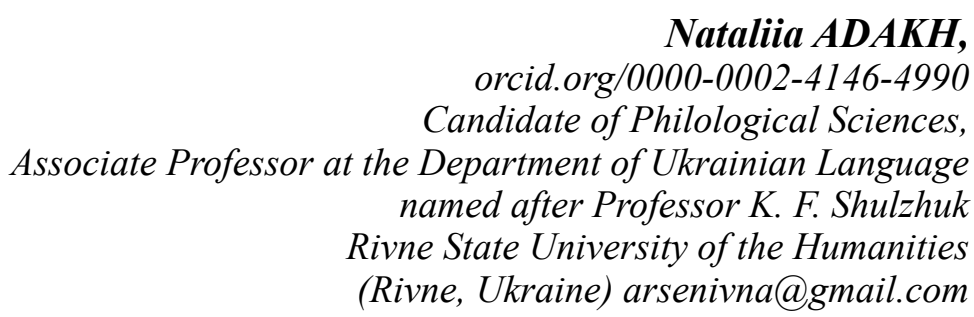


Алах Н., Гаврилюк Н. Авторські мексичні новотвори релігійної тематики в поезії...

$\begin{array}{r}\text { Nataliia HAVRYLIUK, } \\ \text { orcid.org/0000-0003-0225-3258 }\end{array}$
Candidate of Philological Sciences,
Associate Professor at the Department of Ukrainian Language
named after Professor K. F. Shulzhuk
Rivne State University of the Humanities
(Rivne, Ukraine) gavryluk.nat@gmail.com

\section{AUTHOR'S NEOLOGISMS OF RELIGIOUS THEME IN THE POETRY OF VASYL BARKA}

In modern linguistics, the vocabulary for designating religious concepts has repeatedly become the subject of research by scientists. However, most scientific investigations cover mainly the features of the usual vocabulary of artistic, journalistic and confessional styles. Neological vocabulary on this topic, recorded in literary texts, was considered only in isolated works. The proposed article analyzes the semantic features of author's neologisms on religious themes, found in the poetry of $V$. Barka.

The analysis of the factual material made it possible to single out among the entire corpus of new formations to designate religious concepts of innovation with the following differential semes: "happy", "happiness, bliss"; "candle”; "prayer"/"work of religious content"; "divine power"; "altar"; "clothes"; "church utensils"; "a building where services are performed"; "death/end"; "hell”. It is noted that these innovations are marked mainly by positive evaluative semantics. A negative coloration is characteristic of new formations, in the semantic structure of which semes "torment/ martyr"; "enemy of faith" are distinguished.

The lexico-semantic group of names of persons associated with the religious sphere is analyzed separately. It was revealed that the author's names of persons are often the contextual synonyms for usual lexemes, being significantly more expressive in comparison.

Particular attention is paid to the author's nominations on religious topics with symbolic significance. In this aspect, the author's neologisms with differential semes "snake"/"dragon"; "thunder"/"lightning" are analyzed in detail. It is observed that V. Barka, addressing religious beliefs, points to the eternal struggle between God and the devil, good and evil, to the conditional confrontation between light and darkness. This counterbalance is presented in occasional nouns that enter into antonymous relations, as a result of which we have an example of neological antonyms, which is generally not characteristic of the occasional word formation of a single poet.

It is stated that the use of sacred vocabulary and the creation of new words on its basis, which are organically woven into the poetic context of the relevant subject, is specific for $V$. Barka, since religion, especially Christianity and the Bible, had a great influence on V. Barka's worldview.

Key words: author's neologisms, lexical innovation, sacred vocabulary, seme.

Постановка проблеми. Лексика на позначення релігії та церкви наприкінці XX - поч. XXI ст. неодноразово ставала предметом дослідження мовознавців (В. В. Німчук, С. К. Богдан, М. В. Скаб, Л. В. Струганець, А. А. Ковтун, Т. М. Берест та ін.), однак дослідження здійснювалися переважно на матеріалі узуальної лексики художнього, публіцистичного і конфесійного стилів. Неологічна лексика релігійної тематики, що зафіксована у художніх текстах, проаналізована лише в поодиноких працях (В. В. Максимчук). У наш час у мовознавстві простежується посилена увага науковців до нових слів. Над проблемами неології працює багато дослідників (Г. М. Вокальчук, Ж. В. Колоїз, О. О. Жижома, О. В. Кирилюк та ін.). Здійснюється аналіз словотвірних, стилістичних, лексикосемантичних особливостей авторських лексичних новотворів (далі - АЛН).

Аналіз досліджень. Л. В. Струганець вирізняе такі мікрогрупи номінацій: назви богослужбових відправ; номени видів церковного співу; назви духовних осіб; найменування одягу духовних осіб, частин їх убрання; лексеми на позначення частин божого храму; назви церковних обрядів; найменування предметів християнського обряду (Струганець, 2010: 207-208). А. А. Ковтун, досліджуючи модифікацію семантики найменувань богослужбових реалій в українському художньому дискурсі XX століття, описує процес збагачення внутрішньої лексико-семантичної організації групи найменувань богослужбових реалій традиційними та інноваційними для сакральних понять значеннями (Ковтун, 2009: 186-190).

В. В. Максимчук, досліджуючи авторські лексичні новотвори 3 компонентами релігійно-християнської тематики на матеріалі творчості поетів Рівненщини, виокремлює тематичні групи компонентів на позначення релігійних понять у структурі авторських інновацій (Максимчук, 2013).

Мета статті - проаналізувати семантичні особливості авторських лексичних новотворів релігійної тематики, зафіксованих у поезії В. Барки. Мета зумовила такі завдання: 1) виокремити диференційні семи новотворів, з'ясувати їхню 
конотацію; 2) описати авторські новотвори релігійної тематики із символічним значенням.

Виклад основного матеріалу. В. Барка - поетфілософ, концепція модернізму якого корінням своїм торкається вічних, навколобожних чи Божних джерел, які для нас доступні та розмірами невимірні, як і невичерпні (Вірний, 1998: 51).

У творчому доробку В. Барки зафіксовано 1300 лексичних інновацій. Тематична група АЛН на позначення релігійних понять налічує майже 60 неолексем (близько 5\%), серед яких переважають оказіональні іменники й прикметники (переважно це складні номінації).

Для В. Барки характерне використання сакральної лексики і створення на її основі нових слів, які органічно вплітаються в поетичний контекст відповідної тематики. Поет зазначає, що найкращим підручником поезії $є$ книга вселенського життя, відкрита над всіма бібліотеками (Вірний, 1998: 51): ангелолюдство, антихристичник, богозамінний, всесвіт-ікона, страстотерпник, псалмоспівник, псалмоспівецьь, олтарність, церква-небостан, світоіконник, світлоризник.

Створюючи такі слова, за образною характеристикою М. Г. Жулинського, «поет наче прислухається до голосу святих архангелів, виловлюючи звуки християнської любові та доброти...», які згодом переводить «у слова-іскри великої почуттєвої сили» (Жулинський, 2003: 61).

На світогляд В. Барки великий вплив мала релігія, особливо християнство і Біблія. Відомо, що саме під впливом 66-ої книги Біблії - Апокаліпсису - був написаний роман у віршах «Свідок для сонця шестикрилих» у 4 томах - твір глибокої релігійно-міфологічної образно-значеннєвої семантики (Жулинський, 2003: 61).

Релігія для В. Барки стала своєрідним «простором перебування». Це той притулок, де поет відчув свою значущість, де зміг віднайти «втрачений душевний рай». Його релігія, як зазначає О. О. Маланій, - це не тільки основи християнської моралі і звернення до Біблії та іiі сюжетів, - це передусім своєрідний світ, побудований на розбитих ілюзіях, на переоцінених цінностях, на повному самозреченні (Маланій, 2003: 11). Навколишній світ є творінням божим, пронизаним смисловими аналогіями Божої присутності (Головань, 2003: 13).

Аналіз фактичного матеріалу дозволяє виділити 3-поміж усього корпусу новотворів на позначення релігійних понять інновації з такими диференційними семами:

- «щасливий», «щастя, блаженство»: сад-рай, райськість, раӥзм, рай-вертоград, троянднолі- лейний (едем), зверхблаженний, всеблаженний, найблаженніш;

- «свічка»: многосвічничок, семисвіччя, стосвічник;

- «молитва»/«твір релігійного змісту»: молитвеннично, псалмічність, псалмоспівещь, псалмоспівник, псальмик;

- «божественна сила»: самосвятість, святовінечність, святовклінно;

- «жертовник»: біловівтарний, олтарність, надпрестолля;

- «одяг»: стихарний, стихарність, світлоризник;

- «церковне приладдя»: лампадність, олтарність, біловівтарний;

- «будівля, де відбуваються богослужіння»: світ-храм, святиня-храм, иерква-небостан;

- «смерть/кінець»: гробник, гробівниия, гробовість, могильність, могилитися;

- «пекло»: жах-ад, найпекляніший, пеклокрилець, пекло-яма, підпекелець.

Наведені інновації відзначаються здебільшого позитивною оцінною семантикою: ...мій порадник! псальмик мій сердечний, / став при дверях неба мріти (Барка, 1979: 226); Вивіска 3 иарського золота на брамі, / літери діямантні: / «Тут - раӥзм!» (Барка, 1992: 357); Так - трачену в прибоях століть, вертають / святовінечність вівтарну (Барка, 1992: 131); Святовклінно 3 тополями колосся / проскомідією змоглося (Барка, 1992: 179); Від зору первосвященика в мітрі -/ фіялки нестримні: / колірно помріти! / Молитвеннично підожуть (Барка, 1992: 310); Любо! мимо йдучи, сонця кущик / найблаженніш віє в тиші (Барка, 1979: 60).

Негативне забарвлення характерне для новотворів, у семантичній структурі яких виділяються семи «муки/мученик»: найпекляніший, страждотний, страстотерпник; «небезпечне місце»: жах-ад, пекло-яма; «противник віри»: антихристичник, храмоборець. Так, семантика інновації храмобореиь розкривається безпосередньо в поезії, а сама інновація винесена автором у назву твору: Благала: ви від сериь дорожчі! - / кров хресна викупила всіх; / покайтеся, з трави вельможиі, / бо задимить пломінний сніг (Барка, 1968: 212).

У тематичній групі номінацій на позначення релігійних понять виокремлюється лексикосемантична група назв осіб. АЛН псалмоспівник, псалмоспівещь позначають «людину (служитель православної церкви), яка допомагає священнику під час богослужіння»: ...npи арфі-сонце псалмоспівець. (Барка, 1992: 189); Древній океан, зді- 
Алах Н., Гаврилюк Н. Авторські мексичні новотвори релігійної тематики в поезії...

йнявши груди, / вигримить, крізь бурю зблисне - / мову, на стострунностях орудних: / вінценосний псалмоспівець (Барка, 1979: 270); Присмирнів океан - ігумен сивий, / книгою псалмоспівник (Барка, 1992: 59).

Назви осіб Життеначальник, життеприклонець $є$ контекстуальними синонімами до узуальної назви Бога і означають «надприродну істоту, що керує вчинками людей»: Враз: виручі підмур'я струснувши / світоскладу - розсвіт править; / бо Життсначальник, вічно сущий, / воскресає: стати в иарстві (Барка, 1979: 214); Назаря Життсначальник! всесвятістю приклоняти; / киплять, як медами гречок, вали в океані (Барка, 1992: 125); ...стрічати в блискавиччях від престолу - / Життеначальника, що в славі (Барка, 1992: 290); А ви до мужнього життеприклонця / звертаєтесь, як діти - як малі (Барка, 1968: 73). Зазначені новотвори на позначення назв осіб вживаються з позитивною оцінною семантикою.

Серед назв осіб виділяються також інновації 3 негативною конотацією в семантиці, як-от: пеклокрилець, підпекелеиь, що містять диференційну сему «мешканці пекла»: То: між небом лижуть $i$ землею / пеклокрильці «воздух» тайний (Барка, 1979: 247); У Бога я то вірю, / у підпекельця - ні! (Барка, 1992: 37). Крім представлених назв осіб 3 негативним забарвленням, у мовотворчості В. Барки є номінації із семою «змій»/《дракон», які часто згадуються у Біблії, а у творах несуть символічне значення: драконня, драконство, потворавасиліск, драконяно, звіро-змій, горе-змій.

Зі змієм, як винуватцем зла, бореться початок світу, істини і добра, і в цій боротьбі породжується життя у природі фізичній і моральній. Світ і тепло протиставляються боротьбі з темнотою і холодом. Світ описується у вигляді сонця, а тьмаце ніч, гроза, хмари (Костомаров, 1994: 223, 258). В. Барка, звертаючись до релігійних вірувань, вказує на вічну боротьбу Бога і чорта, добра i зла, на умовне протистояння між світлом (світом у значенні «світла») і темрявою, що експліцитно представлено в словах-символах, які виступають твірними для інновацій. Боротьба світла (сонця) тьми (ночі, хмар, грози) відбувається ще в язичницькій міфології слов'яно-руського народу (Костомаров, 1994: 259). В. Барка на противагу змієві ставить Бога як синтеза абсолютної досконалості. Бог у біблійному значенні - «творець усього сущого, символ вічності, незалежності, мудрості» (БЭ-02, 2002: 52-53). Ця противага представлена в оказіональних іменниках, що вступають між собою в антонімічні відношення: підпекелець - життеприклонець, Життєначаль- ник; пекло-яма - надсвіття, надземність. Отже, маємо приклад неологічних антонімів, що загалом не $\epsilon$ характерним для оказіональної словотворчості якогось одного поета.

Символічне значення мають також авторські лексичні новотвори із семами «грім», «блискавка». Грім у християнстві асоціювався з карою за гріхи (НКС-03, 2003: 91). Блискавка сприймалась як вираження Божого гніву, що карає грішних (Кононенко, 1996: 105-106). Водночас спалах блискавки асоціюється із світом, просвітленням (Керлот, 1994: 328). Зазначені природні явища не залежали від людини, тому в уявленні українців вони стали носіями внутрішніх потрясінь, переживань: ...ну, i дощі; ну, i грозовинник, / крізь душу, від мене виник... (Барка, 1992: 118); За гріх: блискавичняться кари: / на зловийників - зграї сказністю скреготали; Блискавичняться кари: за гріх, / бо кожен довільно злом захворів. (Барка, 1992: 95).

Демон у християнстві - злий дух, диявол (ВТСУМ, 2005: 238). Дракон у міфології багатьох народів - потвора, чудовисько у вигляді крилатого вогнедишного змія (СУМ, т. II, 1971: 405). Дракон у християнстві - це символ диявола, який протистоїть Богові (Баешко, 2007: 130). Новотвори із зазначеними семами символізують зло, жорстокість: Коли демоння в помлі-заметілі / вгримить пір'їнами, долині иілій / куди з тополями втекти?.. (Барка, 1968: 153); Димним криком біля небозводів / догрозилося демоння... (Барка, 1979: 141); По сфері духу демон-твердокрил, / кажан гріха, як блискавка, ширяє... (Барка, 1992: 98); Бо залізнені рої драконня, / вбивчі! (Барка, 1992: 299); Всевишній, зглянься і драконство змий... (Барка, 1992: 118); Зверх: найсиньобровімі надходять тучі, / блискавичними голками виити степ м'ятучий... / терзаний криваво - звіроновично! знову: / в смак червоному драконству (Барка, 1992: 390); Драконяно: в коронах иарськости, пренедарма - / сичали на сиріт $і$ вдів, по зграблених домах (Барка, 1992: 339). Дракона часто пов'язують зі змієм.

Релігійна лексика $€$ однією 3 характерних ознак ідіостилю В. Барки, оскільки поет використовує стилістично марковані біблійні поняття, представлені такими кореневими морфемами, які служать твірними основами для інновацій: щасливий - блаженн-, губи - yст-: Любо! мимо йдучи, сония кущик / найблаженніш віє в тиші (Барка, 1979: 60).

Як відомо, поняття інтенсивності ознаки формується тоді, коли предмети порівнюються не за ознакою, а за мірою іiї вияву. Найвищий ступінь 
порівняння означає, що в одному предметі є найбільше певної якості: найпекляніші (дуже важкі) муки, найпренесамовитіша (дуже безтямна) міна, найпроменистіша (дуже осяйна) радість. Оказіональні ад'єктиви саме 3 такими граматичними особливостями (найвищий ступінь порівняння) у поетичному лексиконі автора не випадкові. Їх поява значною мірою зумовлена особливостями релігійного світосприйняття поета: вживання прикметникових форм вищого та найвищого ступенів порівняння, що експліцитно виражають емоційно-оцінний значеннєвий компонент, характеризують ставлення віруючої особи до об'єктів поклоніння, притаманні саме для релігійних текстів (Лук'янчук, 2008: 9). Крім того, частотне використання прикметників синтетичної форми найвищого ступеня порівняння свідчить про максимальний вияв почувань та емоцій у ставленні до Бога (Лук'янчук, 2008: 14).

На думку науковців, релігійне, християнське світовідчуття В. Барки особливо відчутні у зрілій поезії митця (Маланій, 2003: 11). Релігійний простір поета наповнений різноманітними образами та мотивами. Якщо простежити дати появи авторських новотворів релігійної тематики, то побачимо, що лише кілька з них утворені в 40-х роках: пломінноликий, пекло-яма, жах-ад, підпекелець, пророк-словодар, подарунок-смирна. Семантика представлених інновацій має здебільшого негативне забарвлення. АЛН, зафіксовані у «зрілій поезії» (60-90-і роки), характеризуються здебільшого позитивною конотацією, як-от: раїзм, святовінечність, найблаженніш, райськість, самосвятість.

Часто В. Барка створював інновації 3 метою пошуку вдалої рими. Інновація подарунок-смирна утворена шляхом поєднання двох узуальних слів. Як відомо, смирна - ароматична смола, яка в давні часи вважалася цінним подарунком царям (БЭ-02, 2002: 641): Він [владика. - Н.A.] добився трудно в сторону загірну, / принести від ицарства подарунок-смирну (Барка, 1992: 125).

Юкстапозит тернок-вінечник, утворений від біблійного словосполучення терновий вінець (вінок, покладений на голову Господа, що символізує страждання (НТС-06, т. 1, 2006: 344): Смутний у місяия тернок-вінечник: / зверх окликів з двірчяя віолончельних; / над прірвою погрозно прочерленить - / вселенности поріг... (Барка, 1992: 212).

Більшість АЛН на позначення номінацій релігійної тематики експресивні: всесвіт-ікона, пророк-словодар, світоіконник. Особливою ж експресивністю відзначається лексична інновація сточоломбитство. Оказіональний іменник утворений поєднанням основ слів: компонента сто, іменника чоло в орудному відмінку та дієслова бити із суфіксом -ств(о). В українській мові фразеологізм чолом бити означає «уклінно просити кого-небудь про щось» (НТС-06, т. 1, 2006: 99). Новотвір сточоломбитство вживається із значенням «безліч разів просити Бога про щось»: Бісам, під маскою блискоти на перунстві, / мов скований при аднівщині перепутній, / сточоломбитство влупить (Барка, 1992: 337).

Висновки. Лексичні інновації релігійної тематики В. Барки представлено номінаціями різних частиномовних класів. 3-поміж зафіксованих АЛН переважають лексичні інновації 3 позитивною конотацією, що містять диференційні семи «щасливий», «щастя, блаженство»; «свічка»; «молитва»/«твір релігійного змісту»; «божественна сила» та ін. Меншою кількістю представлені новотвори з негативною конотацією, яка наявна в авторських номінаціях 3 диференційними семами «муки/мученик»; «противник віри». Аналіз поезій В. Барки за хронологічним критерієм дозволив простежити таку тенденцію: у ранніх творах виявлені новотвори релігійної тематики мають здебільшого негативну конотацію, а в «зрілій поезії» (60-90-і роки) наявні переважно авторські номінації з позитивним забарвленням. Назви осіб є контекстуальними синонімами до загальновживаних слів. У доробку В. Барки наявні АЛН релігійної тематики, що мають символічне значення. Це зумовлене провідними у творчості поета-філософа, поета-модерніста, поета-символіста ідейно-тематичними настановами, що пояснюється тяжінням автора до християнства, грунтовним вивченням Біблії.

Перспективним видається здійснення подальших системних досліджень, які передбачатимуть виявлення тенденцій та закономірностей у галузі оказіонального словотворення.

\section{СПИСОК ВИКОРИСТАНИХ ДЖЕРЕЛ}

1. Баешко Л. С., Гордиенко А. Н., Гордиенко А. Н. Энциклопедия символов / под. ред. О. В. Перзашкевича. Москва : Эксмо, 2007. 304 с.

2. Барка В. Лірник. Київ : Вид-во «Орій» при УКСП «Кобза», 1992. 688 с.

3. Барка В. Лірник: Вибрані поезії. Нью-Йорк : Вид-во Нью-Йоркської Групи, 1968. 301 с.

4. Барка В. Океан: Лірика. Т. 3. Київ : Вид-во «Орій» при УКСП «Кобза», 1992. 322 с.

5. Барка В. Океан: Лірика: 2-е вид. Нью-Йорк : Слово, 1979. Ч. 2. 284 с. 
6. БЭ-02: Библейская энциклопедия / рук. проєкта В. Бутромеев. Москва : ОЛМА-ПРЕСС, 2002. 768 с.

7. Вірний М. Портрет поета. Рівне : Діва. 1998. 200 с.

8. ВТСУМ: Великий тлумачний словник сучасної української мови (з дод. і допов.) / уклад. і голов. ред. В. Т. Бусел. Київ, Ірпінь : ВТФ «Перун», 2005. 1696 с.

9. Головань Т. П. Естетична природа поетичного мислення Василя Барки : автореф. дис. на здобуття наук. ступеня канд. філол. наук : 10.01.01. Київ, 2003. 20 с.

10. Жулинський М. Г. Василь Барка - культуролог і літописець долі українського народу. Народна творчість та етнографія. 2003. № 4. С. 56-66.

11. Керлот Х. Э. Словарь символов. Москва : REFL-book, 1994. 608 c.

12. Ковтун А. А. Модифікація семантики найменувань богослужбових реалій в українському художньому дискурсі XX ст. Лінгвістичні студї̈ : зб. наук. праць. 2009. Вип. 19. С. 186-190.

13. Кононенко В. І. Символи української мови. Івано-Франківськ : Плай, 1996. 272 с.

14. Костомаров Н. И. Славянская мифология. Слов'янська міфологія. Київ, 1994. С. 201 - 256.

15. Лук'янчук С. В. Епітет у конфесійному стилі сучасної української мови (функціонально-семантичний аспект) : автореф. дис. на здобуття наук. ступеня канд. філол. наук : 10.02.01. Київ, 2008. 19 с.

16. Максимчук В. В. Авторські лексичні новотвори з компонентами релігійно-християнської тематики (на матеріалі творчості поетів Рівненщини). Синопсис: текст, контекст, медіа. 2013. № 2. URL: http://nbuv.gov.ua/UJRN/ stkm 2013215.

17. Маланій О. О. Художній часо-простір поезій Василя Барки : автореф. дис. ... канд. філол. наук : 10.01.01. Київ, 2003. $21 \mathrm{c.}$

18. НКС-03: Настольная книга священнослужителя : в 8 т. Киев : Свято-Успенская Почаевская Лавра, 2003. T. IV. $824 \mathrm{c}$.

19. НТС-06: Новий тлумачний словник української мови : в 3 т. / укл. В. Яременко, О. Сліпушко. Київ : Аконіт, 2006.

20. СУМ: Словник української мови : в 11 т. / ред. колег. І. К. Білодід (голова) та ін. Київ : Наук. думка, 1970-1980.

21. Струганець Л. Параметризація релігійної лексики в авторській автоматичній інформаційній системі. Науковий вісник Чернівецького наиіонального університету імені Юрія Федьковича : зб. наук. праць / наук. ред. Б. І. Бунчук. Чернівці : Чернівецький нац. ун-т, 2010. Вип. 509-511: Слов'янська філологія. С. 204-213.

\section{REFERENCES}

1. Baeshko L. S., Gordienko A. N., Gordienko A. N. Entsiklopediya simvolov [Encyclopedia of symbols] / pod. red. O. V. Perzashkevicha. Moskva: Eksmo, 2007. 304 p. [in Russian].

2. Barka V. Lirnyk [Liryst]. Kyiv : Vyd-vo "Orii" pry UKSP "Kobza", 1992. 688 p. [in Ukrainian].

3. Barka V. Lirnyk: Vybrani poezii [Liryst: Selected poetry]. Niu-York: Vyd-vo Niu-Yorkskoi Hrupy, 1968. 301 p. [in Ukrainian].

4. Barka V. Okean: Liryka [Ocean: Lyrics]. T. 3. Kyiv : Vyd-vo "Orii" pry UKSP "Kobza", 1992. 322 p. [in Ukrainian].

5. Barka V. Okean: Liryka [Ocean: Lyrics]: 2-e vyd. Niu-York: Slovo, 1979. Ch. 2. 284 p. [in Ukrainian].

6. BE-02: Bibleyskaya entsiklopediya [Biblical encyclopedia] / ruk. proekta V. Butromeev. Moskva: OLMA-PRESS, 2002. 768 p. [in Russian].

7. Virnyi M. Portret poeta [Portrait of a poet]. Rivne: Diva. 1998. 200 p. [in Ukrainian].

8. VTSUM: Velykyi tlumachnyi slovnyk suchasnoi ukrainskoi movy (z dod. i dopov.) [Large explanatory dictionary of the modern Ukrainian language (with additions)] / uklad. i holov. red. V. T. Busel. Kyiv, Irpin: VTF "Perun", 2005. 1696 p. [in Ukrainian].

9. Holovan T. P. Estetychna pryroda poetychnoho myslennia Vasylia Barky [Aesthetic nature of Vasyl Barka's poetic thinking]: avtoref. dys. na zdobuttia nauk. stupenia kand. filol. nauk: 10.01.01. Kyiv, 2003. 20 p. [in Ukrainian].

10. Zhulynskyi M. H. Vasyl Barka - kulturoloh i litopysets doli ukrainskoho narodu [Vasyl Barka - a culturologist and chronicler of the fate of the Ukrainian people]. Narodna tvorchist ta etnohrafiia. 2003. No. 4. Pp. 56-66 [in Ukrainian].

11. Kerlot H. E. Slovar simvolov [Dictionary of symbols]. Moskva: REFL-book, 1994. 608 p. [in Russian].

12. Kovtun A. A. Modyfikatsiia semantyky naimenuvan bohosluzhbovykh realii v ukrainskomu khudozhnomu dyskursi XX st. [Modification of the semantics of the names of liturgical realities in the Ukrainian artistic discourse of the $20^{\text {th }}$ century]. Linhvistychni studii: zb. nauk. prats. 2009. Vyp. 19. Pp. 186-190 [in Ukrainian].

13. Kononenko V. I. Symvoly ukrainskoi movy [Symbols of the Ukrainian language]. Ivano-Frankivsk: Plai, 1996. 272 p. [in Ukrainian].

14. Kostomarov N. Y. Slovianska mifolohiia [Slavic mythology]. Kyiv, 1994. Pp. 201-256 [in Russian and Ukrainian].

15. Lukianchuk S. V. Epitet u konfesiinomu styli suchasnoi ukrainskoi movy (funktsionalno-semantychnyi aspekt) [Epithet in the confessional style of the modern Ukrainian language (functional-semantic aspect)]: avtoref. dys. na zdobuttia nauk. stupenia kand. filol. nauk: 10.02.01. Kyiv, 2008. 19 p. [in Ukrainian].

16. Maksymchuk V. V. Avtorski leksychni novotvory z komponentamy relihiino-khrystyianskoi tematyky (na materiali tvorchosti poetiv Rivnenshchyny) [Author's lexical innovations with components of religious-Christian themes (based on the works of poets of Rivne region)]. Synopsys: tekst, kontekst, media. 2013. No. 2. Retrieved from: http://nbuv.gov.ua/UJRN/ stkm_2013_2_15 [in Ukrainian].

17. Malanii O. O. Khudozhnii chaso-prostir poezii Vasylia Barky [Artistic time-space of Vasyl Barka's poems]: avtoref. dys. ... kand. filol. nauk: 10.01.01. Kyiv, 2003. 21 p. [in Ukrainian]. 
18. NKS-03: Nastolnaya kniga svyaschennosluzhitelya [Clergyman's Handbook]: v 8 t. Kiev: Svyato-Uspenskaya Pochaevskaya Lavra, 2003. T. IV. 824 p. [in Russian].

19. NTS-06: Novyi tlumachnyi slovnyk ukrainskoi movy [New explanatory dictionary of the Ukrainian language]: $\mathrm{v} 3 \mathrm{t}$./ ukl. V. Yaremenko, O. Slipushko]. Kyiv: Akonit, 2006. [in Ukrainian].

20. SUM: Slovnyk ukrainskoi movy [Dictionary of the Ukrainian language]: v 11 t. / red. koleh. I. K. Bilodid (holova) ta in. Kyiv: Nauk. dumka, 1970-1980. [in Ukrainian].

21. Struhanets L. Parametryzatsiia relihiinoi leksyky v avtorskii avtomatychnii informatsiinii systemi [Parameterization of religious vocabulary in the author's automatic information system]. Naukovyi visnyk Chernivetskoho natsionalnoho universytetu imeni Yuriia Fedkovycha: zb. nauk. prats / nauk. red. B. I. Bunchuk. Chernivtsi: Chernivetskyi nats. un-t, 2010. Vyp. 509-511: Slovianska filolohiia. Pp. 204-213 [in Ukrainian]. 